\title{
A review on Listeria monocytogenes in food: prevalence, pathogenicity, survivability and antibiotic resistance
}

\author{
${ }^{1}$ Wai, G.Y., ${ }^{1, * T a n g, ~ J . Y . H ., ~}{ }^{2}$ New, C.Y. and ${ }^{2}$ Son, R. \\ ${ }^{1}$ Faculty of Bioresources and Food Industry, Universiti Sultan Zainal Abidin (Besut Campus), 22200 Besut, \\ Terengganu. \\ ${ }^{2}$ Faculty of Food Science and Technology, Universiti Putra Malaysia, 43400 \\ Serdang, Selangor, Malaysia
}

\section{Article history:}

Received: 10 April 2019

Received in revised form: 20

May 2019

Accepted: 21 May 2019

Available Online: 3 July 2019

\section{Keywords:}

Listeria monocytogenes,

Prevalence,

Pathogenicity,

Survivability,

Antibiotic Resistance

DOI:

https://doi.org/10.26656/fr.2017.4(1).155

\begin{abstract}
The ubiquitous of Listeria monocytogenes in the environment and in the niche of foods can be related with the ability of the pathogen to survive in adverse conditions, in example, low temperature and $\mathrm{pH}$, high concentrations of salt and bile, oxidative stress and carbon starvation. Besides, most of the human listeriosis are food-borne and $L$. monocytogenes consists of a spectrum of strains with varying virulence and pathogenicity. Moreover, the virulent regulators play a role in facilitating better adaption or persistence of L. monocytogenes in the food environment. This review included prevalence, pathogenicity, survivability and antibiotic resistance of L. monocytogenes in various categories of foods such as meat, seafood, dairy products and vegetables. The recent updates on listeriosis or foodborne cases associated with L. monocytogenes should be studied in order to have a better understanding of their persistence in the food chain and its public health impact especially among the high-risk groups: elderly, infant, pregnant woman and immunocompromised individuals.
\end{abstract}

\section{Introduction}

Listeria monocytogenes is a facultative saprotroph which is present broadly in dirt, plants, ground water and vegetation. It has been related with numerous foodborne diseases to the consumption contaminated foods particularly ready-to-eat products, dairy products, meat and poultry products (Letchumanan et al., 2018). Initially, there were only three genetic lineage that represent the phylogeny of L. monocytogenes. Later, lineage IV was discovered that showed some differences in terms of phylogeny compared to other lineages (Lomonaco et al., 2015). Listeria is a psychrotropic organism which is likely to endure well and to develop gradually at chill temperatures - clarified by the evidence of vast increment of L. monocytogenes within beef carcasses through the production chain until ground beef products (29\%) (Khen et al., 2014). Besides, L. monocytogenes is a halotolerant pathogen with the ability to survive and endure low $\mathrm{pH}$ and high salt environment as Meloni (2015) reported in the prevalence of $45 \%$ L. monocytogenes in Mediterranean-style dry fermented sausages.

There are thirteen isolates of L. monocytogenes that separated according to somatic $(\mathrm{O})$ and flagellar $(\mathrm{H})$, including $1 / 2 \mathrm{a}, 1 / 2 \mathrm{~b}, 1 / 2 \mathrm{c}, 3 \mathrm{a}, 3 \mathrm{~b}, 3 \mathrm{c}, 4 \mathrm{a}, 4 \mathrm{ab}, 4 \mathrm{~b}, 4 \mathrm{c}, 4 \mathrm{~d}$, 4e and 7. (Allerberger, 2003). Li et al. (2018) reported that $1 / 2 a, 1 / 2 b, 1 / 2 c$ and $4 b$ are the strains that frequently isolated from the food in China. In Europe, listeriosis incidence had been increasing for the last few years which may be related to multi-component foods such as sandwiches and mixed salad that supports the growth of Listeria (Lomonaco et al., 2015). Besides, there are studies that showed recombination is possible in the Listeria genome for example between $L$. monocytogenes / L. innocua and this condition may cause certain strains to survive in various environments including adverse conditions (Orsi et al., 2008; den Bakker et al., 2008). According to a meta-analysis review from Iran by Ranjbar and Halaji (2008), the prevalence of L. monocytogenes from human origin was higher (10\%) compared with animal and food resources ( $7 \%$ and $4 \%$ respectively). However, international comparison on the prevalence of $L$. monocytogenes is difficult due to multifactorial nature of $L$. monocytogenes (Ranjbar and Halaji, 2018).

There are certain groups of individuals that have a higher risk to be infected by listeriosis. In the high-risk group, pregnant women are at the highest risk of contracting listeriosis, which can potentially lead to 
miscarriage, stillbirth, preterm birth, and congenital neonatal infections (Vázquez-boland et al., 2017). Nayak et al. (2018) reported that a three-year-old child developed infection due to L. monocytogenes and was treated with IV ceftriaxone. Unfortunately, the child died due to the transmission of transposon from other bacteria that mutually-induce the resistance of L. monocytogenes towards empirically administered antibiotics. Based on the results from the relative risk of listeriosis study, the incidence rate of listeriosis increased with age (especially after age of 45 years old) (WHO and FAO, 2004). The incidence rate was reported by Poulliot et al. (2012) to be 4.7 and 53.8 for population of 45-49 years old and 85 years old respectively.

Over the years, L. monocytogenes remained a 'highlighted' bacterium in the food industrial sector due to its high incidence and mortality rates. Hence, it is necessary to have updated information on the risk profile of $L$. monoctyogenes in order to manage the risk of $L$. monocytogenes in food safety. This review is aimed to discuss the prevalence and antibiotic profile of $L$. monocytogenes in various food matrices recently and the related foodborne outbreaks in Asia countries as continuous updated case-study and review about the spreading of $L$. monocytogenes is important for tracking the source of contamination.

\section{Virulence and pathogenicity}

For L. monocytogenes to infect the host cell successfully, the bacterium not only have to adhere, invade, multiply and spread to neighboring cell but, also require some regulators to monitor the virulence and pathogenicity of bacterium. Table 1 summarizes the required virulence regulators by $L$. monocytogenes (Camejo et al., 2011).
Human can be infected by L. monocytogenes due to human gastrointestinal cells have receptors that facilitates adhesion and internalization of internalin A and B of L. monocytogenes (Buchanan et al., 2017). In addition, L. monocytogenes has different mechanisms that aid in the adaptation of adverse conditions in the gastrointestinal tract of human. For example, the acidic condition of stomach is mediated by the glutamate decarboxylate system and arginine deiminase system of the bacteria and thus, the $\mathrm{pH}$ of bacterial cytoplasm is maintained (Ryan et al., 2009). However, sometimes Premature Stop Codons (PMSC) that happened in internalin A of L. monocytogenes strains (serotype 1/2 a, $1 / 2 b$ and $1 / 2 c$ that frequently isolated from food sample and environmental resources (about 50\%) are not pathogenic and thus will not cause listeriosis (Marquis et al., 2015).

\section{Foodborne outbreaks}

The prevalence of L. monocytogenes in retail raw foods covered most of the common place capitals in China were contemplated with testing of 1036 samples of vegetables, mushrooms, crude meat, seafood and quick-frozen items by which the absolute pervasiveness of L. monocytogenes was $20.0 \%$ (Wu et al., 2015). There was no national clinical listeriosis reconnaissance in China until 2013, however, numerous Chinese medical journals have reported listeriosis reports. One past deliberate survey was directed to delineate the clinical and epidemiologic qualities of listeriosis in China through writing recovery from 1964 to 2010, and the outcomes demonstrated that $52 \%$ of clinical cases were pregnancy-related patients; the most normal clinical appearance was septicemia (46\%), trailed by CNS contamination $(31 \%)$ and central disease or

Table 1. Listeria monocytogenes virulence regulators and their functions.

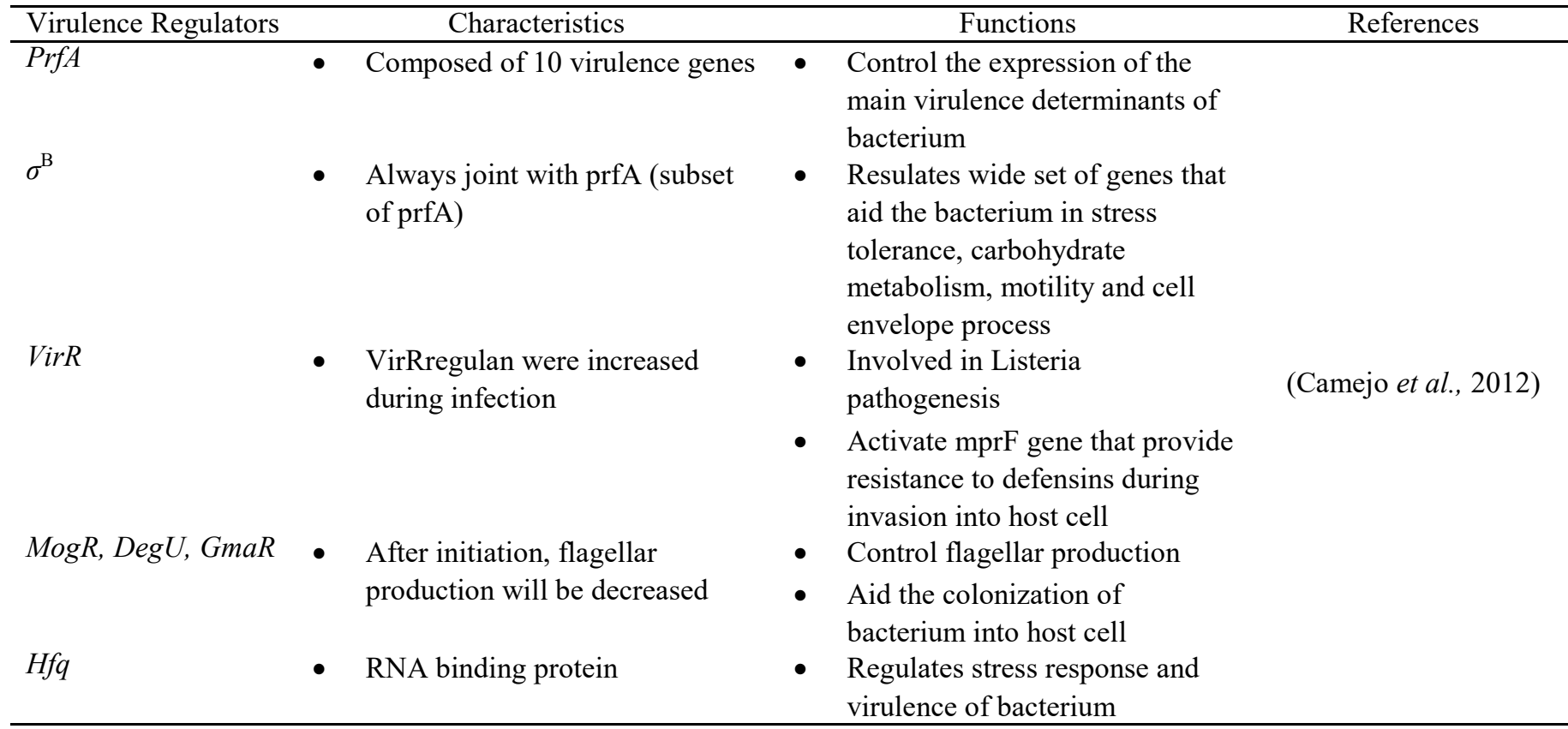


Table 2. Summary of some reported food-borne listeriosis in some Asia Countries

\begin{tabular}{|c|c|c|}
\hline Country & Case Description & Sources \\
\hline Vietnam & $\begin{array}{l}\text { - Three adults were presented with L. monocytogenes meningitis } \\
\text { - Three of them experienced fever, headache and vomiting } \\
\text { - Consumption of contaminated raw milk and soft cheese might be one of the } \\
\text { reason for the outbreak }\end{array}$ & (Chau et al., 2010) \\
\hline China & $\begin{array}{l}\text { - } \begin{array}{l}\text { Eighty-two cases caused by contaminated egg products during preparation and } \\
\text { packaging }\end{array} \\
\text { - Four pregnant woman infected through consumption of roast meat, dairy } \\
\text { products, seafood and preserved vegetables. }\end{array}$ & (Feng et al., 2013) \\
\hline Japan & $\begin{array}{l}\text { - } \quad \text { Eighty six persons had been infected with L. monocytogenes } \\
\text { - } \quad \text { Forty-four percent of patients developed gastroenteritis } \\
\text { - } \quad \text { Outbreak was caused by cheese }\end{array}$ & (Makino et al., 2005) \\
\hline Thailand & $\begin{array}{l}\text { - } \quad \text { An immunocompromised patient had brain abscess due to L. monocytogenes } \\
\text { - } \quad \text { Most probably due to exposure to contaminated shrimp product in company }\end{array}$ & (Treebupachatsakul et al., 2006) \\
\hline Turkey & $\begin{array}{ll}\text { - } & \text { Fifty-four case patients were identified } \\
\text { - } & \text { Eight died and three pregnant women had fetal deaths } \\
\text { - } & \text { Turkey deli-meat was the source of multistate outbreak }\end{array}$ & (Gottlieb et al.,2006) \\
\hline
\end{tabular}

gastroenteritis $(23 \%)$, and the general case-casualty rate was 26\% (Feng et al., 2013). In the United States, the Centers for Disease Control and Prevention (CDC) assesses that listeriosis is in charge of around 1,600 cases and 260 deaths for each year (Morrison et al., 2018). The general EU reported rate of listeriosis was 0.46 cases per 100,000 population with a case-casualty rate of $17.7 \%$. In Asia, there were few listeriosis outbreak reported in some Asia countries as shown in Table 2.

\section{Meat}

Alewy et al. (2016) reported that among different types of red meat from the study in Dharma Governorate, prevalence of L. monocytogenes is the highest from cattle $(26 \%)$, trailed by goat meat $(25 \%)$ and sheep meat $(17.9 \%)$ and therefore, red meat was proved to be the vehicles of transmission of L. monocytogenes to human. In country with four seasons, there was a statistically significant effect by the seasonal variation on the occurrence of L. monocytogenes as shown in study in Southern Italy that the number of meat derived products (raw pork sausage and entrails lamb rolls) were higher in spring and autumn by which the pathogen was detected in January, March and October but none for the samples in February, June, July, August and November (D'Ostuni et al., 2016). It is noteworthy that both of the study in Malaysia and Egypt, the isolation rate of $L$. monocytogenes from beef burger were high which was $4.0 \%$ and $22.9 \%$, respectively, in fact, the added spice could not prevent the growth of L. monocytogenes on raw meat effectively (Wong et al., 2012; Reda et al., 2016). In Thailand, a study showed that improper application of hygienic or good manufacturing practices had caused the contamination of L. monocytogenes in samples of fresh frozen chicken meat and RTE chicken products $(2.5 \%$ and $0.2 \%)$ respectively as there was no contamination detected in the primary production stages. However, L. monocytogenes was detected in the slaughterhouse and RTE processing plants (Kanarat and Sukhapesna, 2011). The oxygen level, temperature and time of storage could be the factors that contributed to the growth of $L$. monocytogenes. Cell counts of $L$. monocytogenes in beef was higher (5-7 log CFU/g) when stored at $22^{\circ} \mathrm{C}$ compared with $7^{\circ} \mathrm{C}$. Besides, the growth rate of L. monocytogenes was the lowest when stored in anaerobic condition (Al-qadiri et al., 2015).

Over the last couple of decades, the expansive usage of antibiotics in human and animals, has significantly added to the development and spread of antimicrobial resistance foodborne pathogens including $L$. monocytogenes (Wilson et al., 2018). For example, a study done in Shanghai, China showed that isolates of $L$. monocytogenes $(5.83 \%)$ from some of the meat products such as duck, chicken, pork and beef are resistant towards tetracycline ( $\mathrm{Su}$ et al., 2016). Previously, penicillin, ampicillin and aminoglycoside are an effective treatment for listeriosis. However, in a study done in Turkey showed that some strains of $L$. monocytogenes $(6.1 \%)$ isolated from raw meat showed resistant to ampicillin and the isolates are said to harbor the virulence gene of $h l y A$, act , inl $A$, inlB, inlC, inlJ, prfA,plcA and iap (Arslan et al., 2018). In southern China, a study showed that secondary contamination is the major reason that cause the wider resistance range of antibiotics in isolates $(10.2 \%)$ from pork and its products in the market (Li et al., 2016).

\section{Seafood}

Smoked fish, especially cool smoked salmon, which is mainstream in the food industry of Ireland and Scotland, ought to be of worry because it is always 
processed as a ready-to-eat (RTE) food. Cold smoking process tend not to have sufficient microbial inactivation steps that could decontaminate L. monocytogenes from the crude material (Rotariu et al., 2013). Over 21 months of sampling period, there were $4.8 \%$ and $10 \%$ of smoked salmon contamination with L. monocytogenes from two food processing facility respectively in Ireland (Leong et al., 2015). Besides, there was a study that demonstrated raw fish samples and the fish samples from the open-air market can lead to zoonotic potential of listeriosis as there were $72.1 \%$ of $L$. monocytogenes belonged to serovars $1 / 2 a, 4 b$ and $1 / 2 b$ recovered from the samples. Furthermore, $14 \%$ of $L$. monocytogenes isolates possessed more than one antimicrobial resistance genes that resulted significant resistance to tetracycline $(27.9 \%)$, trailed by ampicillin (20.9\%), cephalothin, penicillin and streptomycin (16.3\%) (Jamali et al., 2015).

The transcriptomic analysis revealed that $L$. monocytogenes able to survive in salmon by upregulating the cobalamin biosynthesis pathway in order to utilize ethanolamine as a nitrogen source and 1,2 -propanediol as a carbon source from salmon and thus facilitate adaption of the bacterium in vacuum-packed cold-smoked salmon (Tang et al., 2015). Besides, salmon is believed to be a common or native source for isolation of T4 pulsotype in Ireland and T4 is a strain that harbored Tn6188 transposon gene which related to stress resistance, like resist to commonly used sanitizer (BC sanitizer) which is an alcohol based sanitizer in food processing facility and thus support the occurrence and persistence of $L$. monocytogenes in seafood processing facilities and smoked salmon (Leong et al., 2015). Moreover, the good adaptability of $L$. monocytogenes to cold condition also offer an advantage for the survivability of $L$. monocytogenes in fish product as demonstrated by Liu et al. (2016), L. monocytogenes are able to multiply critically (1.5 to $7.0 \log \mathrm{CFU} / \mathrm{g}$ ) during refrigerated storage while in 12 weeks of frozen storage $\left(-18^{\circ} \mathrm{C}\right)$, less than $1-\log$ unit of reductions were observed in tuna samples.

\section{Dairy products}

In 2015, although the rate of listeria contamination on the ice-cream products were low which is 8 cells $/ g$ (unable to support the growth and development of $L$. monocytogenes), listeriosis outbreak still could happen in a condition that most purchasers of the items won't turn out to be sick (Pouillot et al., 2016). In Europe, the first reported listeriosis outbreak was associated with fresh cheese (Linnan et al., 1988) and from an EU baseline survey (EFSA, 2013), there are $0.47 \%$ sample of cheese at retail tested positive for $L$. monocytogenes. Furthermore, there was another study in Turkey demonstrated that the risk of $L$. monocytogenes contamination in dairy products was still low, by which only two cheese samples positive for $L$. monocytogenes $(2.35 \%)$ but none from the raw milk ( $0 \%$ ) (Aygun and Pehlivanlar, 2006). The survival of L. monocytogenes can be varied according to different types of cheese, for example the growth of the pathogen is quite impossible in the hard cheese compared with soft or semi-soft cheeses due to lower $\mathrm{pH}$ and moisture content (Gérard et al., 2018). For example, a study showed that $41.17 \%$ isolates of $L$. monocytogenes harbored the serotypes, $1 / 2 \mathrm{a}, 1 / 2 \mathrm{~b}$ and $4 \mathrm{~b}$, from a Brazilian soft cheese (Da Silva et al., 1998). However, in Chile, no contamination of Listeria spp. in hard cheese (Cordano and Rocourt, 2001). The dairy farm environment can be the source for the survival and dissemination of L. monocytogenes from the livestock in the food chain due to poor silage quality and insufficient hygiene. A total of 38 isolates of $L$. monocytogenes from four dairy farms in east Tennessee, USA. The most worrying part is that 19 isolates from 38 harbored high frequency of antimicrobial resistance gene floR $(66 \%)$ and followed by others such as penA (37\%), $\operatorname{str} \mathrm{A}(34 \%)$, tet $\mathrm{A}(32 \%)$ and $\operatorname{sulI}(16 \%)$ which resulted most isolates resistant to ampicillin (92\%), rifampicin and rifamycin $(84 \%)$, tetracycline $(45 \%)$ and penicillin (40\%) (Srinivasan et al., 2005).

Tolerance response is correlated with the survivability of $L$. monocytogenes in cheese and dairy environment such as acid response, sigma regulators mechanisms, osmotolerance, oxidative stress, heat and cold tolerance and cross-protection (due to sublethal processing) (Melo et al., 2015). In fact, a study showed that sub-lethal stresses such as exposed to adverse condition in food chain may facilitate survival of $L$. monocytogenes through the stimulation of antibiotic resistance responses in L. monocytogenes strain. For example, the antibiotic resistance of dairy isolates increased when salt concentration increased to $12 \%$ at pH 5 and temperature declined to $10^{\circ} \mathrm{C}$ from $37^{\circ} \mathrm{C}$ (AlNabulsi et al., 2015).

\section{Vegetables}

Agroecosystem is known to be a commonplace where L. monocytogenes is known to be present particularly in the vegetables and soil. Soni et al. (2014) demonstrated $10 \%$ of vegetables (brinjal, cauliflower, dolichos-bean, tomato, chappan-kadu and chilli) and 5\% soil samples from a farm tested positive for $L$. monocytogenes. RTE vegetables can be vehicles for transmission of L. monocytogenes as Sant'Ana et al. (2012) reported that $3.1 \%$ of the samples in Brazil were positive with $L$. monocytogenes belonged to the serotype $1 / 2 b$ and $4 b$. Moreover, most isolates are able to survive 
when being exposed to $125 \mathrm{ppm}$ of chlorine-based disinfectant for 3 mins. In Malaysia, "ulam" which is a local salad dish that was commonly eaten raw has been reported to be contaminated by $L$. monocytogenes. Ponniah et al. (2010) reported that Japanese parsley $(31.3 \%)$ and yardlong bean (27.2\%) were frequently detected for positive L. monocytogenes.

In Brazil, De Vasconcelos Byrne et al. (2016) reported that one isolate of $L$. monocytogenes from RTE vegetable show resistance to penicillin while in Nigeria, Ieren et al. (2013) reported that about $64.3 \%$ of $L$. monocytogenes isolated from salad vegetables exhibit resistance to more than 4 antibiotics. The fresh produce growing environment and the formation of biofilm are believed to be the factors that support the survivability of L. monocytogenes in fresh produce. L. monocytogenes is always cycled in the food chain that involved contaminated soil, vegetables, human and animals (Zhu et al., 2017). For example, fertilizers used that contained the bacterium can caused the bacterium to transform from saprophytic to pathogenic when it enters human or animal, further spreading the pathogens to consumers (Rahman and Noor, 2012). A study demonstrated that after 48 hours of incubation, biofilms of $L$. monocytogenes on green leaf lettuce cannot be removed by any types of sanitizers such as ozone $(2 \mathrm{mg} / \mathrm{L})$, chlorine $(100 \mathrm{mg} / \mathrm{L})$ and organic acid $(0.50 \mathrm{~g} / 100 \mathrm{~g}$ ascorbic acid). As a result, the biofilm embedded with bacterial cells was clearly visible in the SEM images (Ölmez et al., 2010). Besides, the temperature of storage or display at retail could play a role in the survivability of $L$. monocytogenes in vegetable, for example Tang et al. (2018) reported that the positive samples from wetmarket was lower $(7 \%)$ due to the psychrotrophic properties of $L$. monocytogenes.

\section{Conclusion}

L. monocytogenes is a pathogen that is ubiquitously present in the environment and a variety of food. Its survivability and persistence in the food matrixes and processing environment make it an important pathogen as one of the causal agents of foodborne poisoning. Serotype $1 / 2$ a strains of $L$. monocytogenes are frequently isolated from the food matrices or the environment while serotype $4 \mathrm{~b}$ strains are frequently associated with real episodes of human listeriosis. To make things worse, emergence of multiple antibiotic resistance strains poses challenges to the clinical treatment for invasive infection among high-risk groups. The data on the evolution of the multiple antibiotic resistance should be constantly up to date in order to mitigate the risk.

\section{Conflict of Interest}

Authors declare no conflict of interest.

\section{Acknowledgement}

This review paper is being supported by the International Foundation for Science, Sweden (E-52372F). The authors would like to thank Ms. Fei Ying Chong from SMK Tengku Mahmud for the English editing.

\section{References}

Allerberger, F. (2003). Listeria: Growth, phenotypic differentiation and molecular microbiology. FEMS Immunology Medicine Microbiology, 35(3), 183189. https://doi.org/10.1016/S0928-8244(02)00447-9

Alewy, D., Ba-salamah, H.A., Shater, A.-R., Sanabani, A.S.Al., Abd, F.M. and Galil, A. (2016). Prevalence of Listeria monocytogenes in Red Meat in Dhamar Governorate / Yemen. International Journal of Medical and Health Research, 2(12), 73-78.

Al-qadiri, H., Sablani, S.S., Ovissipour, M., Al-alami, N., Govindan, B. and Rasco, B. (2015). Effect of oxygen stress on growth and survival of Clostridium perfringens, Campylobacter jejuni, and Listeria monocytogenes under different storage conditions. Journal of Food Protection, 78(4), 691-697. https:// doi.org/10.4315/0362-028X.JFP-14-427

Al-Nabulsi, A.A., Osaili, T.M., Shaker, R.R., Olaimat, A.N., Jaradat, Z.W., Zain Elabedeen, N.A. and Holley, R.A. (2015). Effects of osmotic pressure, acid, or cold stresses on antibiotic susceptibility of Listeria monocytogenes. Food Microbiology, 46, 154 -160. https://doi.org/10.1016/j.fm.2014.07.015

Arslan, S. (2018). Prevalence and antimicrobial resistance of Listeria species and subtyping and virulence factors of Listeria monocytogenes from retail meat. Journal of Food Safety, 39(9), e12578. https://doi.org/10.1111/jfs.12578

Aygun, O. and Pehlivanlar, S. (2006). Listeria spp. in the raw milk and dairy products in Antakya, Turkey. Food Control, 17(8), 676-679. https:// doi.org/10.1016/j.foodcont.2005.09.014

Buchanan, R.L., Gorris, L.G.M., Hayman, M.M., Jackson, T.C., and Whiting, R.C. (2017). A review of Listeria monocytogenes: An update on outbreaks, virulence, dose-response, ecology, and risk assessments. Food Control, 75, 1-13. https:// doi.org/10.1016/j.foodcont.2016.12.016

Camejo, A., Carvalho, F., Reis, O., Leitão, E., Sousa, S. and Cabanes, D. (2011). The arsenal of virulence factors deployed byListeria monocytogenesto 
promote its cell infection cycle. Virulence, 2(5), 379 -394. https://doi.org/10.4161/viru.2.5.17703

Chau, T.T.H., Campbell, J.I., Schultsz, C., Chau, N.V.V., Diep, T.S., Baker, S., Chinh, N.T., Farrar, J.J. and van Doorn, H.R. (2010). Three adult cases of Listeria monocytogenes meningitis in Vietnam. PLoS Medicine, 7(7), e1000306. https:// doi.org/10.1371/journal.pmed.1000306

Cordano, A.M. and Rocourt, J. (2001). Occurrence of Listeria monocytogenes in food in Chile. International Journal of Food Microbiology, 70, 175 -178. https://doi.org/10.1016/S0168-1605(01)005335

D’Ostuni, V., Tristezza, M., De Giorgi, M.G., Rampino, P., Grieco, F. and Perrotta, C. (2016). Occurrence of Listeria monocytogenes and Salmonella spp. in meat processed products from industrial plants in Southern Italy. Food Control, 62, 104-109. https:// doi.org/10.1016/j.foodcont.2015.10.025

Da Silva, M.C.D., Hofer, E. and Tibana, A. (1998). Incidence of Listeria monocytogenes in cheese produced in Rio de Janeiro, Brazil. Journal of Food Protection, 61(3), 354-356. https:// doi.org/10.4315/0362-028X-61.3.354

De Vasconcelos Byrne, V., Hofer, E., Vallim, D.C. and de Castro Almeida, R.C. (2016). Occurrence and antimicrobial resistance patterns of Listeria monocytogenes isolated from vegetables. Brazilian Journal of Microbiology, 47(2), 438-443. https:// doi.org/10.1016/j.bjm.2015.11.033

den Bakker, H.C., Didelot, X., Fortes, E.D., Nightingale, K.K. and Wiedmann, M. (2008). Lineage specific recombination rates and microevolution in Listeria monocytogenes. BMC Evolutionary Biology, 8, 277. https://doi.org/10.1186/1471-2148-8-277

EFSA. (2013). Analysis of the baseline survey on the prevalence of Listeria monocytogenes in 542 certain ready-to-eat foods in the EU, 2010-2011 Part A: Listeria monocytogenes prevalence 543 estimates. EFSA Journal, 11(6), 3241. https://doi.org/10.2903/ j.efsa.2013.3241

Feng, Y., Wu, S., Varma, J.K., Klena, J.D., Angulo, F.J. and Ran, L. (2013). Systematic review of human listeriosis in China, 1964-2010. Tropical Medicine and International Health, 18, 1248-1256. https:// doi.org/10.1111/tmi.12173

Gérard, A., El-Hajjaji, S., Niyonzima, E., Daube, G. and Sindic, M. (2018). Prevalence and survival of Listeria monocytogenes in various types of cheese-A review. International Journal of Dairy Technology, 71(4), 825-843. https://doi.org/10.1111/14710307.12552
Gottlieb, S.L., Newbern, E.C., Griffin, P.M., Graves, L.M., Hoekstra, R.M., Baker, N.L., Hunter, S.B., Holt, K.G., Ramsey, F., Head, M., Levine, P., Johnson, G., Schoonmaker-Bopp, D., Reddy, V., Kornstein, L., Gerwel, M., Nsubuga, J., Edwards, L., Stonecipher, S., Hurd, S., Austin, D., Jefferson, M.A., Young, S.D., Hise, K., Chernak, E.D. and Sobel, J. (2006). Listeriosis Outbreak Working Group. Multistate outbreak of Listeriosis linked to Turkey deli meat and subsequent changes in US regulatory policy. Clinical Infectious Diseases, 42 (1), 29-36. https://doi.org/10.1086/498113

Ieren, I. (2013). Occurrence and antibiotic resistance profile of Listeria monocytogenes in salad vegetables and vegetable salads sold in Zaria, Nigeria. African Journal of Food Science, 7(9), 334-338. https:// doi.org/10.5897/AJFS2013.1036

Jamali, H., Paydar, M., Ismail, S., Looi, C.Y., Wong, W.F., Radmehr, B. and Abedini, A. (2015). Prevalence, antimicrobial susceptibility and virulotyping of Listeria species and Listeria monocytogenes isolated from open-air fish markets. BMC Microbiology, 15(1), $144 . \quad \mathrm{https} / /$ doi.org/10.1186/s12866-015-0476-7

Kanarat, S. and Sukhapesna, J. (2011). Prevalence of Listeria monocytogenes in chicken production chain in Thailand. The Thai Veterinary Medicine, 41(2), 155-161.

Khen, B.K., Lynch, O.A., Carroll, J., McDowell, D.A. and Duffy, G. (2014). Occurrence, antibiotic resistance and molecular characterization of Listeria monocytogenes in the beef chain in the Republic of Ireland. Zoonoses and Public Health, 62(1), 1117. https://doi.org/10.1111/zph.12106

Leong, D., Alvarez-Ordonez, A., Zaquali, S. and Jordan, K. (2015). Examination of Listeria monocytogenes in seafood processing facilities and smoked salmon in the Republic of Ireland. Journal of Food Protection, 78(12), 2184-2190. https:// doi.org/10.4315/0362-028X.JFP-15-233

Letchumanan, V., Wong, P., Goh, B., Ming, L.C., Pus-, P., Wong, S.H., Nurul-Syakima, A. and Lee, L. (2018). A review on the characteristics, taxanomy and prevalence of Listeria monocytogenes. Progress in Microbes and Molecular Biology, 1(1), a0000007.

Li, L., Olsen, R. H., Ye, L., Wang, W., Shi, L., Yan, H. and Meng, H. (2016). Characterization of antimicrobial resistance of Listeria monocytogenes strains isolated from a pork processing plant and its respective meat markets in Southern China. Foodborne Pathogens and Disease, 13(5), 262-268. https://doi.org/10.1089/fpd.2015.2087

Li, W., Bai, L., Fu, P., Han, H., Liu, J. and Guo, Y. 
(2018). The Epidemiology of Listeria monocytogenes in China. Foodborne Pathogens and Disease, 15(8), 459-466. https://doi.org/10.1089/ fpd.2017.2409

Linnan, M.J., Mascola, L., Lou, X. D., Goulet, V., May, S., Salminen, C., Hird, D.W., Yonekura, M.L., Hayes, P., Weaver, R., Audurier, A., Plikaytis, B.D., Fannin, S.L., Kleks, A. and Broome, C.V. (1988). Epidemic listeriosis associated with Mexican-style cheese. New England Journal of Medicine, 319(13), 823-828.

https://doi.org/10.1056/

\section{NEJM198809293191303}

Liu, C., Mou, J. and Su, Y.-C. (2016). Behavior of Salmonella and Listeria monocytogenes in Raw Yellowfin Tuna during Cold Storage. Foods, 5(1), 16. https://doi.org/10.3390/foods5010016

Lomonaco, S., Nucera, D. and Filipello, V. (2015). The evolution and epidemiology of Listeria monocytogenes in Europe and the United States. Infection, Genetics and Evolution, 35, 172-183. https://doi.org/10.1016/j.meegid.2015.08.008

Makino, S.-I., Kawamoto, K., Takeshi, K., Okada, Y., Yamasaki, M., Yamamoto, S. and Igimi, S. (2005). An outbreak of food-borne listeriosis due to cheese in Japan, during 2001. International Journal of Food Microbiology, 104(2), 189-196. https:// doi.org/10.1016/j.ijfoodmicro.2005.02.009

Melo, J., Andrew, P.W. and Faleiro, M.L. (2015). Listeria monocytogenes in cheese and the dairy environment remains a food safety challenge: The role of stress responses. Food Research International, 67, 75-90. https://doi.org/10.1016/ j.foodres.2014.10.031

Meloni, D. (2015). Presence of Listeria monocytogenes in Mediterranean-Style Dry Fermented Sausages. Foods, 4(4), 34-50. https://doi.org/10.3390/ foods 4010034

Morrison, H.A., Lowe, D., Robbins, J.R. and Bakardjiev, A.I. (2018). In vivo virulence characterization of pregnancy-associated Listeria monocytogenes infections. Infection and Immunity, 86, e00397-18. https://doi.org/10.1128/IAI.00397-18

Nayak, N., Baral, N., Bahadur N., Gokhale, S., Hamal, D., Bhatta, D.R. and Rao K.S. (2018). Listeria meningitis in a three-year-old immunocompetent child: a case report from a tertiary care hospital in Nepal. Medical College Journal, 20(4), 187-190.

Ölmez, H. and Temur, S.D. (2010). Effects of different sanitizing treatments on biofilms and attachment of Escherichia coli and Listeria monocytogenes on green leaf lettuce. LWT - Food Science and Technology, 43(6), 964-970. https://doi.org/10.1016/ j.lwt.2010.02.005

Orsi, R.H., Sun, Q. and Wiedmann, M. (2008). Genomewide analyses reveal lineage specific contributions of positive selection and recombination to the evolution of Listeria monocytogenes. BMC Evolutionary Biology, 8, 233. https:// doi.org/10.1186/1471-2148-8-233

Pouillot, R., Klontz, K.C., Chen, Y., Burall, L.S., Macarisin, D., Doyle, M., Bally, K.M., Strain, E., Datta, A.R., Hammack, T.S., and Van Doren, J.M. (2016). Infectious dose of Listeria monocytogenes in outbreak linked to ice cream, United States, 2015. Emerging Infectious Diseases, 22(12), 2113-2119. https:// doi.org/10.3201/eid2212.160165

Ponniah, J., Robin, T., Paie, M.S., Radu, S., Ghazali, F. M., Kqueen, C.Y., Nishibuchi, M., Nakaguchi, Y. and Malakar, P.K. (2010). Listeria monocytogenes in raw salad vegetables sold at retail level in Malaysia. Food Control, 21(5), 774-778. https:// doi.org/10.1016/j.foodcont.2009.09.008

Pouillot, R., Hoelzer, K., Jackson, K.A., Henao, O.L. and Silk, B.J. (2012). Relative risk of Listeriosis in Foodborne Diseases Active Surveillance Network (FoodNet) sites according to age, pregnancy, and ethnicity. Clinical Infectious Diseases, 54(Suppl. 5), S405-S410. https://doi.org/10.1093/cid/cis269

Rahman, F. and Noor, R. (2012). Prevalence of pathogenic bacteria in common salad vegetables of Dhaka Metropolis. Bangladesh Journal of Botany, 41(2), 159-162. https://doi.org/10.3329/ bjb.v41i2.13442

Ranjbar, R., and Halaji, M. (2018). Epidemiology of Listeria monocytogenes prevalence in foods, animals and human origin from Iran: a systematic review and meta-analysis. BMC Public Health, 18(1), 1057. https://doi.org/10.1186/s12889-018-5966-8

Reda, W., Abdel-Moein, K., Hegazi, A., Mohamed, Y. and Abdel-Razik, K. (2016). Listeria monocytogenes: An emerging food-borne pathogen and its public health implications. Journal of Infection in Developing Countries, 10, 149-154. https://doi.org/10.3855/jidc.6616

Rotariu, O., Thomas, D.J.I., Goodburn, K.E., Hutchison, M.L. and Strachan, N.J.C. (2013). Smoked salmon industry practices and their association with Listeria monocytogenes. Food Control, 35, 284-292. https:// doi.org/10.1016/j.foodcont.2013.07.015

Ryan, S., Begley, M., Gahan, C.G., and Hill, C. (2009). Molecular characterization of the arginine deiminase system in Listeria monocytogenes: Regulation and role in acid tolerance. Environmental and 
Microbiology, 11, 432-445. https://doi.org/10.1111/ j.1462-2920.2008.01782.x

Sant'Ana, A.S., Igarashi, M.C., Landgraf, M., Destro, M.T. and Franco, B.D.G.M. (2012). Prevalence, populations and pheno- and genotypic characteristics of Listeria monocytogenes isolated from ready-to-eat vegetables marketed in São Paulo, Brazil. International Journal of Food Microbiology, 155 (12), 1-9. https://doi.org/10.1016/ j.ijfoodmicro.2011.12.036

Soni, D.K., Singh, M., Singh, D.V. and Dubey, S.K. (2014). Virulence and genotypic characterization of Listeria monocytogenes isolated from vegetable and soil samples. BMC Microbiology, 14(1), 241. https:// doi.org/10.1186/s12866-014-0241-3

Su, X., Zhang, J., Shi, W., Yang, X., Li, Y., Pan, H., Kuang, D., Xu, X., Shi, X. and Meng, J. (2016). Molecular characterization and antimicrobial susceptibility of Listeria monocytogenes isolated from foods and humans. Food Control, 70, 96-102. https://doi.org/10.1016/j.foodcont.2016.04.020

Srinivasan, V., Nam, H.M., Nguyen, L.T., Tamilselvam, B., Murinda, S.E. and Oliver, S.P. (2005). Prevalence of antimicrobial resistance genes in Listeria monocytogenes isolated from dairy farms. Foodborne Pathogens and Disease, 2(3), 201-211. https://doi.org/10.1089/fpd.2005.2.201

Tang, S., Orsi, R.H., den Bakker, H.C., Wiedmann, M., Boor, K.J. and Bergholz, T.M. (2015). Transcriptomic analysis of the adaptation of Listeria monocytogenes to growth on vacuumpacked cold smoked salmon. Applied and Environmental Microbiology, 81(19), 6812-6824. https://doi.org/10.1128/AEM.01752-15

Tang, J.Y.H., Razali, N.A.S., Jalil, L.A., Mat-Sa'ad, S.H., Nakaguchi, Y., Nishibuchi, M. and Radu, S. (2018). Detection of Listeria spp. and Listeria monocytogenes in vegetables by Loop-Mediated Isothermal Amplification (LAMP) and multiplex Polymerase Chain Reaction (PCR). Journal of Fundamental and Applied Sciences, 9(2S), 698-714. https://doi.org/10.4314/jfas.v9i2s.43

Treebupachatsakul, P., Srifeungfung, S. and Chayakulkeeree, M. (2006). Case report brain abscess due to Listeria monocytogenes: first case report in Thailand. Journal of Medicine Association Thai, 89(9), 1516-1520.

Vázquez-boland, J.A., Krypotou, E. and Scortti, M. (2017). Listeria Placental Infection. mBio, 8(3), 1-6. https://doi.org/10.1128/mBio.00949-17

WHO and FAO. (2004). Risk assessment of Listeria monocytogenes in ready-to-eat foods. Technical report. Microbiological Risk Assessment Series 5. Geneva: WHO.

Wilson, A., Gray, J., Chandry, P.S. and Fox, E.M. (2018). Phenotypic and genotypic analysis of antimicrobial resistance among Listeria monocytogenes isolated from Australian food production chains. Genes, 9(2), 80. https:// doi.org/10.3390/genes 9020080

Wong, W.C., Pui, C.F., Tunung, R., Cheah, Y.K., Nakaguchi, Y., Nishibuchi, M. and Son, R. (2012). Prevalence of Listeria monocytogenes in frozen burger patties in Malaysia. International Food Research Journal, 19, 1751-1756.

Wu, S., Wu, Q., Zhang, J., Chen, M., Yan, Z. and Hu, H. (2015). Listeria monocytogenes prevalence and characteristics in retail raw foods in China. PLOS ONE, 10(8), e0136682. https://doi.org/10.1371/ journal.pone. 0136682

Zhu, Q., Gooneratne, R. and Hussain, M. (2017). Listeria monocytogenes in fresh produce: Outbreaks, prevalence and contamination levels. Foods, 6(3), 21. https://doi.org/10.3390/foods6030021 